\title{
Konteyner Taşımacılığı Pazarında Sürdürülebilir Liman Rekabetinin Belirleyicileri: Sistematik Literatür Araştırması
}

\author{
Sedat BAŞTUĞ 1 , Soner ESMER ${ }^{2}$ \\ Özet
}

Türkiye'nin Stratejik Planları kapsamında, denizcilik alanında strateji belgeleri ve ana planlar olușturularak ülkemizin konteyner liman kapasitesi ve rekabetçiliğinin arttırılması ve liman işletmeciliği meslek standartlarının geliştirilmesi amaçlanmaktadır. Tüm bu stratejilerin başarılı olması için, doğası gereği uluslararası bir alanda hizmet veren Türkiye limanlarının, bölgesindeki diğer ülke limanlarıyla rekabet edebilecek seviyeye ulaşması gerekmektedir. Bu yüzden, çalışma konteyner limanlarımızın sürdürülebilir rekabetçi üstünlüğü açısından literatürde yer alan güncel liman seçim kriterlerini araștırmayı hedeflemektedir. Araştırma yöntemi olarak sistematik literatür taraması tercih edilmiştir. Araștırma sonucunda maliyet faktörlerinin hiyerarşide en yüksek değere sahip olduğu tespit edilmiștir.

Anahtar kelimeler: Konteyner taşımacılığı, Rekabetçi üstünlük, Liman seçim kriterleri, Sürdürülebilirlik Jel Kodu: M3, M30, M31

\section{Determinants of Sustainable Port Competitiveness for Transit Container Market: A Systematic Literature Review}

\section{Abstract}

Within the scope of Turkish Strategic Plan, it is to be aimed to improve port competitiveness with capacity expansion and develop occupational standards by creating strategic documents and master plans. For all these strategies to be successful, Turkish ports should be reached to a level of which can compete with other rival ports by the nature of the market. Therefore, the study aims to investigate the current port selection criteria in the literature in terms of the sustainable competitive advantage of container ports. A systematic literature review was preferred as the research method. As a result of the research, the cost criterion is found to have the highest values in the hierarchy.

Keywords: Container transportation, Competitive advantage, Port selection criteria, Sustainability. Jel Codes: M3, M30, M31

ATIF ÖNERİsi (APA): Baştuğ, S., Esmer, S. (2021). Konteyner Taşımacıllı̆ı Pazarında Sürdürülebilir Liman Rekabetinin Belirleyicileri: Sistematik Literatür Araştırması. İzmir İktisat Dergisi. 37(1). 34-52. Doi: 10.24988/ije.767420

1 Dr.Öğr.Üyesi, İskenderun Teknik Üniversitesi, Barbaros Hayrettin Gemi İnşaatı ve Denizcilik Fakültesi, İskenderun / HATAY, EMAIL: sedat.bastug@iste.edu.tr ORCID: 0000-0002-7121-2882

2 Prof. Dr., Dokuz Eylül Üniversitesi, Denizcilik Fakültesi, Buca / İZMIR, EMAIL: soneresmer@gmail.com ORCID: 00000002-0614-7818 


\section{GíRIS}

UNCTAD (Birleşmiş Milletler Ticaret ve Kalkınma Konferansı) göre, 2019 yılında dünyada taşınan toplam 197,6 milyon TEU (twenty-foot equivalent unit, 20 kadem uzunluğunda konteyner) konteynerin 24,4 milyonu (\%12) Uzak Doğu - Avrupa rotasında taşınmıștır. Yine aynı sene, dünya limanlarında ise elleçlenen toplam konteyner sayısı yaklaşık 800 milyon TEU'luk bir hacme ulaşmaktadır. Türkiye, Uzak Doğu-Avrupa ana deniz ticareti ve konteyner hattı rotasında, özellikle Karadeniz ülkelerinin dış ticaret yükleri için önemli bir aktarma ve geçiş güzergâhında yer almaktadır. Liman tesislerimizin yüksek kapasitelerine rağmen liman operasyonlarında karşıllaşlan verimsizlik, zayıf hizmet sunumu ve ticari operasyonlardaki sorunlar nedeniyle sürdürülebilir liman rekabetinde bir çok liman güçlükle karşılaşmaktadır.

Limanlarımızın bölgelerinde rekabet güçlerini arttırmaları için yönetim ve stratejik açıdan doğru yönlendirilmeleri gerekmektedir.

Limanlar deniz ve kara taşımacılığının ara yüz bağlantısı ve entegre bir platform olarak, lojistik, üretim, bilgi aktarımı ve uluslararası ticarete hizmet vermekte ve aynı zamanda geri sahanın ekonomik gelişimi için bir atlama tahtası işlevi görmektedir. Bu fonksiyonların düzgün bir şekilde yerine getirilmesi için limanların verimli ve etkili bir şekilde gemilere ve diğer ulaştırma modlarına hizmet etmesi gerekmektedir. Ticaretteki öneminden dolayı limanlar, ekonomik refahın ulusal ve uluslararası ekonomilere transferinde çok kritik bir rol üstlenmektedir.

Bu yüzden bu araştırma konteyner limanlarımızın sürdürülebilir rekabetçi üstünlüğe ulaşması için izleyeceği kriterlerin tespitini amaçlamaktadır. Bu amaç doğrultusunda hedeflenen araştırma soruları şöyledir:

1. Konteyner taşımacılığı pazarında sürdürülebilir liman rekabetini belirleyen temel kriterler nelerdir?

2. Liman rekabeti belirleyicileri içinde literatürde hangi kriter ön plana çıkmaktadır?

Araştırmada ilk olarak teorik çerçeve oluşturulmuş, sonrasında metodoloji detaylı bir şekilde açıklanmıştır. Son kısımda ise, araştırmanın bulgularına ve gelecekte planlanan çalışmalar için önerilere yer verilmiştir.

\section{TEORIKK ÇERÇEVE}

1990'larda dünya ticaretindeki hızlı artış özellikle konteyner liman sektöründe yeni gelişmelere neden olurken, dünya liman ağlarının yeniden yapılanması nedeniyle liman rekabeti daha da yoğun bir hale gelmiştir. Sonrasında endüstriyel pazarların ve entegre olmuş tedarik zincirlerinin egemenliği ile önemli değiş̧imler yaşanmıştır. Bu değişimlerin etkisiyle limanlarda verilen katma değer hizmetlere olan talep artış gösterirken farklı ulaştırma modlarının intermodal ya da çoklu taşımacılık adı altında entegrasyonu önem kazanmıştır. Ticari hayatta dengenin sağlanması ve sürdürülebilirliğin yakalaması için değişim halindeki çevreye uyum, kritik bir öneme sahip olurken, limanlarda sunulan yüksek kaliteli lojistik hizmetler ve ulaştırma sistemlerine yönelik verimli ve etkin entegrasyon hizmetleri önem kazanmıştır (Yeo ve Song, 2006: 911; Baştuğ vd. 2014: 8). Bu yeni eğilimler ile liman rekabet boyutlarının değişimi kaçınılmaz bir hale gelmiştir. Dünyada tüm limanlar mevcut yük akışını korumak ya da geliştirmek için çaba göstermektedirler. Günümüzde özellikle konteyner limanları lokasyon olarak yakın, komşu limanlar ile seviyesi sürekli artan bir rekabet içindedir. Goss (1990: 2) liman rekabetini beş kategoriye ayırmıştır:

1. Belirli bir kıyı kesimi ya da alanda yer alan limanlar arasında rekabet,

2. Farklı ülkelerde hizmet veren limanlar arasında rekabet,

3. Aynı ülke içinde hizmet veren limanlar arasında rekabet,

4. Aynı liman içinde faaliyet gösteren farklı operatörler arasında rekabet,

5. Farklı taşıma modları arasında rekabet. 
Liman rekabetinin analizi ağırlıklı olarak liman seçim kriterleri üzerine yoğunlaşmıştır. Çok az çalışma Porter'ın (1980: 89) sektörlerin rekabetçi avantaj teorisini kapsam dişı bırakmıştır (Robinson, 2002: 242). Günümüzde bir limanın rekabetçi üstünlüğünü birçok faktör tanımlayabilmektedir. Bu faktörlerden bazlları liman tesisinin büyüme imkânı, ekipmanların modernliği, önemli konteyner gemi hatları ile yaptıkları kira anlaşmaları, besleme (feeder) rotalardaki etkinlikleri, diğer limanlara göre fiyat tarifesi ve operasyon verimliliği gibi değişkenler olabilir (Song ve Yeo, 2015: 340). Bahsedilen bu değișkenleri de kapsayan ve liman kullanıcıları (müşterileri) tarafından tercih edilen önemli liman seçim kriterleri aşağıdaki gibidir (Yeo vd., 2008: 911; Esmer ve Çetin, 2013: 515):

1. Varış limanında rıhtımın uygunluğu,

2. Transit yük oranı,

3. Yük elleçleme, transfer ve depolama maliyeti,

4. Geminin ve yükün limana girişi ile ilgili maliyetler,

5. Ana rotalara olan sapma mesafesi,

6. Etkili iç transfer ağı,

7. Terminalde ücretsiz depolama için verilen süre,

8. Yük kayıp ve hasarlar sıklığı,

9. Büyük konteyner gemisi gelme sıklığ

10. Gemi gelme sıklığı ve gemi rotalarının çeşitliliği,

11. Hükümet, yerel otonom yapısı ve özel sektörler,

12. İç taşıma maliyetleri,

13. İntermodal bağlantılar,

14. Önemli yük sahiplerine olan kara mesafesi ve bağlanabilirlik,

15. Temiz su, yakıt ve gemi tedariki hizmetlerinin düzeyi,

16. Gemi varıș ve ayrılıșı için seyir yardımcılarının yeterliliği,

17. Direk okyanus bağlantılı gemilerin sayısı,

18. Liman operasyonlarında uzmanlar ve eğitimli iş gücü,

19. Hızlı cevap verme,

20. Dokümantasyon düzenleme hızı,

21. Limana ulaşılabilirlik,

22. Liman sıkışıklığı,

23. Liman hizmet satışı, promosyonlar,

24. Liman güvenliği,

25. Çalıșma zamanları,

26. Limanın tanınırlığı ve şöhreti,

27. Limandaki gemi sefer programlarının güvenilirliği,

28. Gemi büyüklüğüne göre hizmet kapasitesi,

29. Liman geri sahasındaki serbest bölgelerin büyüklüğü ve faaliyetleri,

30. Yakındaki kentin ekonomik büyüklüğü,

31. Liman bilgi sistemleri ve uygulama kapsamının çok yönlülük düzeyi,

32. Liman çalışanlarının tutarlılığı,

33. Terminal verimliliği,

34. Toplam işlem gören yük miktarı,

35. Yaklaşım kanalı ve rıhtımdaki su derinliği,

36. Sifır bekleme zamanlı hizmet,

37. Günde 24 saat, haftada 7 gün hizmet,

38. Liman seçim kriterlerine bölgesel gelişim imkanları,

39. Yerel alt yapı koşulları, 
40. Yüke yakınlık.

Yeo ve diğerleri 2008 yılında yaptıkları çalışmada belirli bir bölge için liman rekabetine odaklanmış ve rekabetçi limanların belirlenmesi için liman hizmetleri (hızlı cevap verme, günde 24 saat, haftada 7 gün hizmet, sıfır bekleme zamanlı hizmet), hinterland bağlantısı (liman operasyonlarında uzmanlar ve eğitimli iş gücü, liman geri sahasındaki serbest bölgelerin büyüklügü ve faaliyetleri, toplam işlem gören yük miktarı), erișilebilirlik (varış limanında rıhtımın uygunluğu, liman sıkışıklığı), elverişlilik (yaklaşım kanalı ve rıhtımdaki su derinliği, liman bilgi sistemleri ve uygulama kapsamının çok yönlülük düzeyi, liman çalışanlarının tutarlılığı), lojistik maliyetler (iç taşıma maliyetleri, geminin ve yükün limana girişi ile ilgili maliyetler, terminalde ücretsiz depolama için verilen süre), bölgesel merkez olma (limana ulaşllabilirlik, ana rotalara olan sapma mesafesi) ve diğer limanlarla bağlanabilirlik (önemli yük sahiplerine olan kara mesafesi ve bağlanabilirlik, etkili iç transfer ağı) kriterlerini ve alt kriterlerini yukarıda sıralanan 37 kriter içinden seçerek kullanmışlardır. Liman seçim kriterleri, aynı zamanda liman rekabetinin temel belirleyicileridir. Geçmişte liman rekabeti, liman kullanıcısının birden fazla limanı seçebilmesine odaklanırken günümüzde liman rekabeti çok daha karmaşık bir hal almıștır. Bugün liman rekabeti, limanların çok boyutlu kullanımı ile lojistikle ilgili çeşitli taleplerin yerine getirildiği tesisler olarak çok farklı faktörler ile belirlenmektedir. Liman rekabeti akademisyenler tarafından farklı şekillerde tanımlanmıştır. Genel bir ifade ile liman rekabeti, limanların rekabetçi üstünlüklerine göre birbirleri ile rekabet etmesi olarak düşünülebilir. Liman rekabetini, liman kullanıcılarının bir limanı seçerken kullandıkları değerlendirme kriterleri belirler (Kim vd., 2016: 189). Song ve Yeo (2004: 341) çalışmasında liman rekabetini etkileyen faktörler olarak limanda işlem gören yük miktarı, limanın sahip olduğu tesisler, limanın coğrafi lokasyonu ve verilen hizmetin seviyesi olarak sıralarken Yap vd. (2006: 170) limanın diğer limanlarla olan bağlanabilirliği üzerine yoğunlaşmıștır. Saeed (2009: 272) geliştirdiği bir doğrusal modelde gemi tipleri, toplam elleçleme, gemi sıklı̆̆ı ve gemi hatlarının uğrak sayıları gibi değişkenler üzerinden analizler yapmıştır. Liman rekabeti konusunda literatüre önemli katkılar sağlayan akademisyenlerden birisi olan Tongzon (2009: 190) çalışmasında liman seçim kriterleri olarak uygun coğrafi lokasyon, düşük liman masrafları, uygun alt yapı, yüksek liman verimliliği, geniş yelpazedeki liman hizmetleri ve limanın diğer limanlarla bağlantıları (bağlanabilirlik) kullanmıştır. Bichou vd. (2014: 1044) liman seçim kriterleri üzerine teorik bir çerçeve geliştirirken öncelikle üç ana kategori oluşturmuş ve bu kategoriler altında alt kategorileri sınıflandırmıştır. Bunlar; rota faktörleri (lokasyon, erişebilirlik, liman bağlantısı, geri saha ağı, sıklık ve transit süre), maliyet faktörleri (navlun oranları, tarifeler ve kapasite) ve hizmet faktörleridir (sıkışıklık, güvenilirlik, esneklik, emniyet ve güvenlik). Sayareh and Alizmini (2014: 76) yaptıkları çalışmada en önemli liman seçim değişkenleri olarak fiziksel kriterler (yeterli su derinliği, liman tesislerinin kapasitesi, rıhtım sayısı, liman lokasyonu, gemi kumanyacılığı ve liman teknolojisi) ve hizmet kriterleri (liman çalıșma süresi, liman tarifeleri, liman güvenliği, liman girişi, işletme maliyeti, uluslararası politikalar, gece seyrüseferi, liman yönetimi, liman çalışanları, gümrük formaliteleri) tespit etmişlerdir. Akbayırlı vd. (2016: 261) kriterleri liman lokasyonu ve hinterland bağlantısı (liman-yol bağlantısı, limandemiryolu bağlantısı, yükün orijine ve varış noktasına olan uzaklığı), liman fiziksel ve teknik altyapısı ve üstyapısı (liman depolama alanı büyüklüğü, liman bilgi teknolojileri, liman ekipmanlarının sayısı, liman ekipmanlarının kalite ve teknolojisi, limanın soğutmalı depolama alanı), liman yönetim ve idaresi (yönetim tipi, liman işletme yönetiminin özelliği), liman hizmet kalitesi (limandaki katma değerli hizmetler, liman hizmetlerinde sunulan güveninirlilik, sosyal sorumluluk, yeşil liman uygulamaları, limanlardaki lojistik hizmetler olarak sıralamaktadır. 
Tablo 1: Literatürde yer alan Liman Seçim Kriterleri ve Alt Kriterlere ilişkin Teorik Çerçeve

\begin{tabular}{|c|c|c|}
\hline \multirow{19}{*}{ 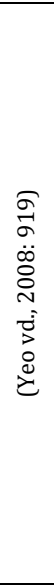 } & Ana Kriterler & Alt Kriterler \\
\hline & \multirow{3}{*}{ Liman hizmetleri } & Hızlı cevap verme \\
\hline & & Günde 24 saat haftada 7 gün hizmet \\
\hline & & Sifir bekleme zamanlı hizmet \\
\hline & \multirow{3}{*}{ Hinterland bağlantısı } & Liman operasyonlarında uzmanlar ve eğitimli iş gücü \\
\hline & & Liman geri sahasındaki serbest bölgelerin büyüklügü ve faaliyetleri \\
\hline & & Toplam işlem gören yük miktarı \\
\hline & \multirow{2}{*}{ Erişilebilirlik } & Varıș limanında rıhtımın uygunluğu \\
\hline & & Liman sıkıșıklığı \\
\hline & \multirow{3}{*}{ Elverişlilik } & Yaklaşım kanalı ve rıhtımdaki su derinliği \\
\hline & & Liman bilgi sistemleri ve çok yönlülük düzeyi \\
\hline & & Liman çalışanlarının tutarlılığı \\
\hline & \multirow{3}{*}{ Lojistik maliyetler } & İç taşıma maliyetleri \\
\hline & & Geminin ve yükün limana giriși ile ilgili maliyetler \\
\hline & & Terminalde ücretsiz depolama için verilen süre \\
\hline & \multirow{2}{*}{ Bölgesel merkez olma } & Limana ulașilabilirlik \\
\hline & & Ana rotalara olan sapma mesafesi \\
\hline & \multirow{2}{*}{ Limanlarla bağlanabilirlik } & Yük sahiplerine olan kara mesafesi ve bağlanabilirlik \\
\hline & & Etkili iç transfer ağı \\
\hline \multirow{11}{*}{ 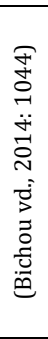 } & \multirow{5}{*}{ Rota faktörleri } & Lokasyon \\
\hline & & Erișebilirlik \\
\hline & & Liman bağlantısı \\
\hline & & Geri saha ağı \\
\hline & & Siklık ve transit süre \\
\hline & \multirow{2}{*}{ Maliyet faktörleri } & Navlun oranları \\
\hline & & Tarifeler ve kapasite \\
\hline & \multirow{4}{*}{ Hizmet faktörleri } & Sıkışıklık \\
\hline & & Güvenilirlik \\
\hline & & Esneklik \\
\hline & & Emniyet ve güvenlik \\
\hline \multirow{33}{*}{ 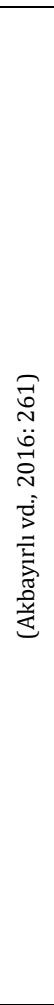 } & \multirow{3}{*}{$\begin{array}{l}\text { Liman lokasyonu ve hinterland } \\
\text { bağlantısı }\end{array}$} & Liman-yol bağlantısı \\
\hline & & Liman-demiryolu bağlantısı \\
\hline & & Yükün orijine ve varıș noktasına olan uzaklığı \\
\hline & \multirow{5}{*}{$\begin{array}{l}\text { Liman fiziksel ve teknik altyapısı } \\
\text { ve üstyapısı }\end{array}$} & Liman depolama alanı büyüklüğü \\
\hline & & Liman bilgi teknolojileri \\
\hline & & Liman ekipmanlarının sayısı \\
\hline & & Liman ekipmanlarının kalite ve teknolojisi \\
\hline & & Limanın soğutmalı depolama alanı \\
\hline & \multirow{2}{*}{ Liman yönetim ve idaresi } & Yönetim tipi \\
\hline & & Liman işletme yönetiminin özelliği \\
\hline & & Limandaki katma değerli hizmetler \\
\hline & & Liman hizmetlerinde sunulan güvenirlilik \\
\hline & & Sosyal sorumluluk \\
\hline & & Yeșil liman uygulamaları \\
\hline & & Limanlardaki lojistik hizmetler \\
\hline & & Liman hizmetlerindeki esneklik \\
\hline & Liman hizmet kalitesi & Özel hizmetler \\
\hline & Liman hizmet kalitesi & Müșterilere yükleme hakkında bilgi sunulması \\
\hline & & Yük kayıp ve hasarlarına ilișkin liman performansı \\
\hline & & Liman güvenliği \\
\hline & & Kullanıcı problemlerine hızlı cevap verebilme \\
\hline & & Liman personelinin davranıș ve tutumları \\
\hline & & Liman personelinin yeterlilikleri \\
\hline & & Bilgi ve tecrübeleri \\
\hline & & Limandaki sıkışıklık \\
\hline & Liman verimliligi ve üretkenliği & Gemilerin limanda kalıș süreleri \\
\hline & & Toplam liman tarife ve maliyeti \\
\hline & & Fiyatlarda esneklik \\
\hline & Liman tarife ve maliyetleri & Ödemelerde kolaylık \\
\hline & & Liman tercihinden kaynaklı toplam lojistik maliyetleri \\
\hline & & Konteyner taşıyan hatların limana uğrak sayısı, \\
\hline & Gemilerin uğrak sayıları ve & Sefer sıklıkları \\
\hline & & Yükler için transit süre \\
\hline
\end{tabular}

Ayrıca liman hizmetlerindeki esneklik, özel hizmetler, müşterilere yükleme hakkında bilgi sunulması, yük kayıp ve hasarlarına ilişkin liman performansı, liman güvenliği, liman kullanıcılarının problemlerine hızlı cevap verme, liman personelinin davranış ve tutumları, liman personelinin yeterlilikleri, bilgi ve tecrübeleri), liman verimliliği ve üretkenliği (limandaki sıkışıklık, gemilerin limanda kalış süreleri), liman tarife ve maliyetleri (toplam liman tarife ve maliyeti, fiyatlarda 
esneklik, ödemede kolaylık, liman tercihinden kaynaklı toplam lojistik maliyetleri) ve konteyner taşıyanlara ait gemilerin uğrak sayıları ve sıklığı (konteyner taşıyan hatların limana uğrak sayısı, sefer sıklıkları, yükler için transit süre) diye belirtmişlerdir.

Genel bir deyişle farklı çalışmalarda liman rekabetini etkileyen farklı faktörlerin değerlendirildiği anlaşılmaktadır. Bu çalışmalar genel olarak liman tesisinin faydalı kullanımı, finansal durumun iyileștirilmesi ve liman yük hacminin geliștirilmesine odaklanmaktadır. Son yıllarda bu kapsamda yapılan ve ISI indeksleri kapsamında yayınlanan çalışmalarda kullanılan kriterlere "Kurumsal Sosyal Sorumluluk" ve "Konteyner Hat Operatörlerinin Kendi Aralarında Yaptıkları İttifaklar" gibi boyutlar eklenmeye başlamıştır (Yuen vd., 2017: 2). Bu çalışmaların uygulama alanı genellikle Avrupa ve Uzak Doğu bölgesidir.

\section{1. Çalışmanın Motivasyonu}

Liman rekabeti üzerine yapılan çalışmalar farklı araştırma alanlarına hitap etse de, mevcut çalışmalar limancılık endüstrisinde yaşanan ekonomik ve teknolojik değişimleri ve sektörün ana itici faktörlerini yorumlamada eksik kalmışlardır (Parola vd., 2016: 118). Ayrıca, hem terminal operatörleri hem de liman kullanıcıları açısından ortak kriterler sunan bir çalışmaya da literatürde rastlanmamıştır. Bu yüzden, gelecekte yapılacak uygulamalı çalışmalar için tüm tarafları ve değişimleri de kapsayan teorik bir çerçevenin belirlenmesine ihtiyaç bulunmaktadır.

Özellikle, öncü belirleyicilerin keşfedilmesi ile çalışmanın liman rekabeti üzerine yapılan tartışmalara da yeni bir boyut kazandıracaktır. Araştırma amacı doğrultusunda liman seçim kriterlerine ilişkin alan yazında sistematik bir literatür taraması yaklaşımı tercih edilmiştir. Sistematik literatür taramaları titiz ve sistemli bir şekilde yürütüldüklerinden ötürü, klasik literatür çalışmalarından ayrılan orijinal çalışmalar olarak görülmektedirler.

\section{ARAŞTIRMA YÖNTEMI}

Bu araştırma konteyner limanlarımızın sürdürülebilir rekabetçi üstünlüğe ulaşması için izleyeceği kriterlerin tespitini amaçlamaktadır. Seuring ve Gold (2012: 545) bu tarz çalışmaların dört aşamadan oluştuğunu belirtmektedir, bunlar; verilerin toplanması, tanımlayıcı istatistikler verilmesi, ana kategorilerin belirlenmesi ve verilerin incelenmesidir. Bu çalışmanın araştırma süreci Seuring ve Gold (2012) çalışmasından adapte edilmiştir (Bakınız Şekil 1).

Şekil 1: Çalışmanın Araştırma Süreci

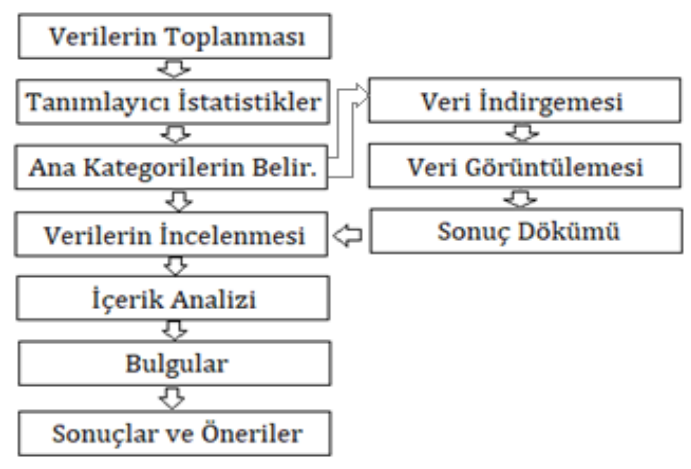

Verilerin toplanması aşamasında ilk örneklem elde edilmiş ve bu çalışmalar, Tablo 2 ve 3'de görüldüğü üzere belirli kriterlere göre elenerek ilk örneklemdeki çalışmalara ulaşılmıştır. Ayrıca, literatürdeki mevcut çalışmaların bu araştırma içinde veya dışında tutulmasını sağlayacak belli kısıtlar/kriterler de (dahili ve harici) konulmuş ve son örneklem ortaya çıkmıştır. Sonraki aşamada kronolojik, ülkelere ve araştırma türlerine göre çalışmalar hakkında tanımlayıcı istatistikler hazırlanmıştır. Ana kategorilerin belirlenmesi, teorik çerçeve doğrultusunda yapılmış ve veri 
indirgeme yapılarak kategorilerin konsolide edilmesi sağlanmıştır. Miles ve Huberman (1994: 91)'na göre ana kategorilerden gelen verilerin incelenmesi aşaması üç temel aşamadan oluşmaktadır. Bu aşamalar: (1) veri indirgenmesi, (2) veri görüntülenmesi, ve (3) sonuç dökümüdür. Tümdengelim yaklaşımında içerik analizine doğru gidebilmek için yeterli miktarda analitik çerçeve olması lazımken, analitik çerçevenin tümevarımsal bir şekilde oluşu incelenen verinin önceden tanımlanmış temalar altında özetlenmesini gerektirir (Mayring, 2000: 5). Böylece veri, aşamalı olarak azaltılır ve yoğunlaştırılır (Eisenhardt, 1989: 59). Bu çalışmada, analitik kategori örüntüsü oluşturmada iki aşamalı süreç geliştirme yaklaşımı önerilmektedir: ilk aşamada, mevcut teori temelinde kategoriler ve alt kriterlerin temel çerçevesi oluşturulduktan sonra, kodlama sürecinde tüm kategoriler konsolide edilmiştir. Veri indirgemesinin devamında alt kriterlere ait kategorilerin kodlamasında iterasyon döngüsü metodu kullanılmıştır.

Son olarak, Seuring ve Gold (2012: 546) içerik analizini iki aşamaya ayırmaktadır. İlk aşamada istatiksel metotlar kullanılarak doküman içeriği incelenirken ikinci aşamada terim ve çıkarımların altında yatan anlamlar yorumlanarak belirli kelime ve kavramların varlığı araştırılmaktadır. Bu aşamalara bağlı olarak oluşturulan kategoriler literatüre ilişkin içerik analizine aktarılmıştır. İçerik analizinin akabinde bulgular tartışılmış ve sonuçlar ile gelecek çalışmalar için öneriler son bölüme eklenmiştir.

\subsection{Verilerin Toplanması}

Verilerin toplanması sürecinde, elektronik veritabanları, zaman akışı ve anahtar kelimeler kullanılarak literatür tarama stratejisi geliștirilmiştir. Bu literatür taraması EBSCO, ProQuest, Scopus, Web of Science, ULAKBİM ve Microsoft Akademik veritabanları taranarak Şubat 2020 tarihinde yapilmıştır.

Ayrıca, literatür taramasını zenginleștirmek için kütüphane taraması da gerçekleştirilmiştir. Sürdürülebilir liman rekabetine ilişkin araştırma yapan birçok yazar (Lam., 2015: 71; Lirn vd., 2014: 72), İngilizce olarak "sustainability","environmental sustainability", "environmental performance indicators", "port competitiveness", "port selection", "modelling”, "container terminal selection", ve "sustainable hinterland" şeklinde anahtar kelimeleri çalışmalarında tercih etmişlerdir.

Ayrıca, bu çalışmada da bu anahtar kelimelere ait Türkçe karşılıkları ("sürdürülebilirlik", "çevresel sürdürülebilirlik", "çevresel performans göstergeleri", "liman rekabeti", "liman seçimi”, "modelleme", "konteyner terminal seçimi" ve "sürdürülebilir geri saha”) ULAKBİM (Ulusal Akademik Ă̆ ve Bilgi Merkezi) veri tabanında taranmak üzere kullanılmıştır (Tablo 2).

Anahtar kelimelerin seçilmesinde liman rekabeti üzerine yazılmış çalışmalarda yer alan anahtar kelimelerden esinlenilmiştir.

Tablo 2: Verilerin Toplanması Sürecinde Literatür Tarama Stratejisi

\begin{tabular}{|c|c|c|c|c|c|c|}
\hline \multirow{2}{*}{ No } & \multirow{2}{*}{ Veri Seti } & \multicolumn{4}{|c|}{ Kisitlar } & \multirow{2}{*}{ Sonuç } \\
\hline & & Arama Sahası & Doküman Türü & Zaman Aralığı & Dil & \\
\hline 1 & EBSCO & Tema & Makale & Tüm Yıllardan Günümüze & İng. & 210 \\
\hline 2 & Proquest & $\begin{array}{l}\text { Tema, Başlık, } \\
\text { Özet, } \\
\text { Anahtar Kelimeler }\end{array}$ & Makale ya da Kritik & Tüm Yıllardan Günümüze & İng. & 110 \\
\hline 3 & Scopus & $\begin{array}{l}\text { Tema, Başlık, } \\
\text { Özet, } \\
\text { Anahtar Kelimeler }\end{array}$ & Makale ya da Kritik & Tüm Yıllardan Günümüze & İng. & 75 \\
\hline 4 & Web of Science & Tema & Makale & Tüm Yıllardan Günümüze & İng. & 52 \\
\hline 5 & Microsoft Akademik & Tema & Makale & Tüm Yıllardan Günümüze & İng. & 33 \\
\hline 6 & ULAKBIMM & Tema & Makale & Tüm Yıllardan Günümüze & Türkçe & 10 \\
\hline \multicolumn{6}{|c|}{ İlk Örneklem } & 490 \\
\hline
\end{tabular}

Albany Üniversite (2018)'sine göre, mantıksal operatörler elektronik veritabanlarında araştırmayı genişletmek veya daraltmak için kelimeler arasında kullanılan özel karakterler ya da karakter 
gruplarıdır. "AND” mantıksal operatörü araştırmayı daraltmak, "OR" operatörü araştırmayı genişletmek için kullanılır. Dolayısıyla literatür taraması bu anahtar kelimeler üzerinden yapılmıştır. Araştırma stratejisi için "AND” ve "OR" operatörleri kullanılmıștır. Anahtar kelimelerin belirlenmesi aşamasından sonra açı ve net bir arama dizisinin ("sustainability" AND "environmental sustainability" OR "environmental performance indicators" OR "port competitiveness" OR "port selection" OR "modelling" OR "container terminal selection" OR "sustainable geri saha") oluşturulması gerekmektedir. Belirlenen arama dizisi sonucu Tablo 3'de görülen sonuçlara ulaşılmıştır.

Tablo 3: Son Örnekleme ilișkin Literatür Tarama Stratejisi

\begin{tabular}{|c|c|c|}
\hline Adımlar & Kriterler & Sonuçlar \\
\hline $\begin{array}{l}\text { 1'inci taramadan } \\
\text { sonraki örneklem }\end{array}$ & $\begin{array}{l}\text { Özet taraması, anahtar kelimeler ve özet içeriği dahil edilerek } \\
\text { yapılmıştır. Bazı anahtar kelimeler ("managerial", "port branding", } \\
\text { "port identity" vb.) araştırmadan çıarılmıştır. Araștırmada } \\
\text { hakemli ve İngilizce olan alan dizinde taranan dergiler } \\
\text { kullanılmıştır. Farklı dillerdeki ve alan dizin haricindeki dergiler } \\
\text { çalışmadan çıarılmıștır. }\end{array}$ & 15 \\
\hline $\begin{array}{l}\text { 2'inci taramadan } \\
\text { sonraki örneklem }\end{array}$ & $\begin{array}{l}\text { Kategori yada tema içermeyen kavramsal çalışmalar, çalışma için } \\
\text { asgari düzeyde bilgi sağlayacağı düşsünüldügünden araștırmadan } \\
\text { çlkarılmışlardır. Ayrıca, Tablo } 3 \text { 'de belirtilen kriterlere uygun } \\
\text { șekilde çalıșmalar eklenmiș yada çıarılmıștır. }\end{array}$ & 10 \\
\hline Ek Kaynaklar & $\begin{array}{l}\text { Arama dizisi içindeki anahtar kelime "sustainability" ve diğer } \\
\text { anahtar kelimeler arasında "OR" mantıksal operatörü kullanılarak } \\
\text { literatür içinde görülmeyen başka kaynak olup olmadığı kontrol } \\
\text { edilmiș ve çıkan farklı kaynaklar çalıșmaya dahil edilmiștir. }\end{array}$ & 8 yeni kaynak \\
\hline \multicolumn{2}{|r|}{ fe } & 33 \\
\hline
\end{tabular}

Sistematik literatür taramasında en önemli nokta, mevcut çalışmaları bu araştırmanın içinde yada dışında tutacak olan kısıtların (dahili ve harici) net bir şekilde tanımlanmasıdır. Tablo 4'de yer alan bu kısıtlar araştırmaya akademik olmayan, alan dışı, farklı dillerde olan çalışmaların elenmesini kolaylaştırmaktadır.

Tablo 4: Literatür Taramasında Kullanılan Kısıtlar

\begin{tabular}{|c|c|}
\hline Dahili Kısıtlar & Harici Kısıtlar \\
\hline Bilimsel dergilerde yayınlanan tam metin çalıșmalar & Akademik olmayan yazı ve derlemeler \\
\hline Ampirik çalıșmalar & Görüșmeler \\
\hline Doktora tezleri & Kitap eleștirileri \\
\hline İngilizce ile yazılmış bilimsel makaleler & Konferans özetleri \\
\hline $\begin{array}{l}\text { Sosyal bilimlerde liman ve sürdürülebilirlik üzerine yapılmış alan } \\
\text { içi çalıșmalar }\end{array}$ & Sosyal bilimler haricinde yapılan alan dışı çalışmalar \\
\hline Teorik çalıșmalar & İngilizce haricinde dillerde yazılmıș eserler \\
\hline \multicolumn{2}{|l|}{ Vaka Analizleri } \\
\hline \multicolumn{2}{|l|}{ Editöre yazılmıș notlar } \\
\hline Tam metin olarak sunulmuș kongre bildirileri & \\
\hline
\end{tabular}

\subsection{Tanımlayıcı İstatistikler}

$\mathrm{Bu}$ kısımda, çalışmanın örneklemini oluşturan çalışmalar üzerinde frekans dağılım tekniği kullanılmıştır. Yeni çalışma alanlarını deneyen araştırmacılar için frekans dağılım tekniği çok faydalıdır. Bu teknik ile içerik analizinin temellerini oluşturacak biçimsel özellikler sunulabilmektedir (Seuring ve Gold, 2012: 547). Tanımlayıcı istatistikler kısmında yazarlara ait yayınların basım yılları, yaptıkları araştırmalar (ampirik, teorik yada kavramsal) incelenmektedir. Aynı zamanda yazarların çalıştıkları sektör ve alanlar da bu analize eklenmiştir. Tanımlayıcı istatistikler kısmı, ana kategorilerin ve alt kategorilerin oluşmasından sonra açıklanacaktır. 


\subsection{Ana Kategorilerin Belirlenmesi}

Çalışmanın teorik çerçevesine bakıldı̆̆ında, (1) liman hizmetleri, (2) hinterland bağlantısı, (3) erişilebilirlik, (4) elverişlilik, (5) lojistik maliyetler, (6) bölgesel merkez olma, (7) diğer (8) limanlarla bağlanabilirlik, (9) rota faktörleri, (10) maliyet faktörleri, (11) hizmet faktörleri, (12) liman lokasyonu ve hinterland bağlantısı, (13) liman fiziksel ve teknik altyapısı ve üstyapısı, (14) liman yönetim ve idaresi, (15) liman hizmet kalitesi, (16) liman verimliliği ve üretkenliği, (17) liman tarife ve maliyetleri, (18) gemilerin uğrak sayıları ve sıklığı liman seçim kriterleri olarak ana kategorilere ayrılmışlardır. Tüm kategoriler çalışmanın amacına uygun bir şekilde sıralanmış ve farklı kaynaklardaki yeterli miktarda bilgi vermeyen çalışmalara ait ana kategoriler araștırmaya dâhil edilmemiştir.

\subsection{Verilerin Analizi}

Verilerin analizi kısmında, yedi ana kategori ve 44 alt kategori oluşmuştur.

Tablo 5: Veri İndirgenmesi Sonucu oluşan Ana Kategori Düzeni

\begin{tabular}{|c|c|c|}
\hline & Ana Kategoriler & Alt Kategoriler \\
\hline \multirow[t]{8}{*}{1} & \multirow{8}{*}{$\begin{array}{l}\text { Hinterland bağlantısı ve } \\
\text { imkanları }\end{array}$} & Liman geri sahalarındaki (hinterland) serbest bölgelerin büyüklüğ̈ ve faaliyetleri \\
\hline & & Toplam işlem gören yük miktarı \\
\hline & & Yük sahiplerine olan kara mesafesi ve bağlanabilirlik \\
\hline & & Etkili iç transfer ağı \\
\hline & & Liman lokasyonu \\
\hline & & Liman-yol bağlantısı \\
\hline & & Liman-demiryolu bağlantısı \\
\hline & & Yükün orijine ve varıș noktasına olan uzaklığı \\
\hline \multirow[t]{8}{*}{2} & \multirow[t]{8}{*}{ Erişilebilirlik } & Varıș limanında rıhtımın uygunluğu \\
\hline & & Liman sıkıșıklığı \\
\hline & & Gemilerin limanda kalıș süreleri \\
\hline & & Konteyner tașıyan hatların limana uğrak sayısı \\
\hline & & Sefer sıklıkları \\
\hline & & Yükler için transit süre \\
\hline & & Limana ulaşlabilirlik \\
\hline & & Ana rotalara olan sapma mesafesi \\
\hline \multirow[t]{2}{*}{3} & \multirow[t]{2}{*}{ Elverişlilik } & Liman bilgi sistemleri ve çok yönlülük düzeyi \\
\hline & & Liman çalışanlarının tutarlılığı \\
\hline \multirow[t]{6}{*}{4} & \multirow[t]{6}{*}{ Maliyet faktörleri } & Tarifeler ve kapasite \\
\hline & & İç taşıma maliyetleri \\
\hline & & Terminalde ücretsiz depolama için verilen süre (Free Time) \\
\hline & & Fiyatlarda esneklik \\
\hline & & Ödemelerde kolaylık \\
\hline & & Liman tercihinden kaynaklı toplam lojistik maliyetleri \\
\hline \multirow[t]{4}{*}{5} & \multirow[t]{4}{*}{ Liman Altyapı ve Üstyapısı } & Liman depolama alanı büyüklüğü \\
\hline & & Liman ekipmanlarının sayısı \\
\hline & & Liman ekipmanlarının kalite ve teknolojisi \\
\hline & & Limanın soğutmalı depolama alanı \\
\hline \multirow[t]{2}{*}{6} & \multirow[t]{2}{*}{ Liman yönetim ve idaresi } & Yönetim tipi \\
\hline & & Liman işletme yönetiminin özelliği \\
\hline \multirow[t]{14}{*}{7} & \multirow[t]{14}{*}{ Hizmet Faktörleri } & Limandaki katma değerli hizmetler \\
\hline & & Liman hizmetlerinde sunulan güvenirlilik \\
\hline & & Sosyal sorumluluk \\
\hline & & Yeşil liman uygulamaları \\
\hline & & Limanlardaki lojistik hizmetler \\
\hline & & Liman hizmetlerindeki esneklik \\
\hline & & Özel hizmetler \\
\hline & & Müșterilere yükleme hakkında bilgi sunulması \\
\hline & & Yük kayıp ve hasarlarına ilișkin liman performansı \\
\hline & & Liman güvenliği \\
\hline & & Liman personelinin davranış, tutumları ve yeterlilikleri \\
\hline & & Hızlı cevap verme \\
\hline & & Günde 24 saat haftada 7 gün hizmet \\
\hline & & Sifır bekleme zamanlı hizmet \\
\hline
\end{tabular}

Özellikle en çok çalışılan alt kriterler belirlenmiş ve teoriye katkısı az olan veya benzeșen alt kriterler analizden çıkarılmıştır. Burada yapılan iş sayesinde ana kategorilerin içinde yer alan tüm alt kriterler 
birbirleriyle karşılaştırılmış, benzeşen alt kriterler aynı ana kategori altında toplanarak veri indirgenmesi aşaması tamamlanmıştır.

Sonuç dökümü aşamasında iterasyon süreci tamamlanan 44 farklı alt kriter, alt kategori olarak belirlenmiştir. Örneğin Bichou (2014) çalışmasındaki rota faktörü bu çalışmada kullanılmayıp, (1) yük sahiplerine olan kara mesafesi, (2) etkili iç transfer ağı, (3) liman-yol bağlantısı, (4) limandemiryolu bağlantısı, (5) yükün orijine ve varış noktasına olan uzaklığı ve (6) lokasyon alt kriterleri olarak limanlarla bağlanabilirlik ana kategorisi altında konsolide edilmiştir (Tablo 5).

\section{TANIMLAYICI İSTATISTIKLER}

Tablo 5'de belirlenen sekiz ana kategori üzerinde verilerin özetlenmesi ve araştırma sonuçlarının yorumlanması için kullanılan ilk adım tanımlayıcı istatistiklerdir. Diğer bir tanımla betimsel istatistik, verilerin istatistiksel olarak derlenmesi, toplanması, özetlenmesi ve analiz edilmesi ile ilgili süreci kapsar (Krippendorff, 2018: 97). Çalışmada tanımlayıcı istatistiklere ilişkin konuların neler olacağına karar vermek için birtakım sorular belirlenmiştir:

1. Liman seçim kriterlerine ilişkin yayınların zaman içindeki dağılımı nedir?

2. Liman seçim kriterlerine ilişkin yayınların basıldıkları dergilere göre dağılımı nedir?

3. Liman seçim kriterlerine ilişkin yayınların ülke bazında dağılımı nedir?

4. Çalışmalarda hangi tür analiz yöntemleri uygulanmıştır?

Sonraki bölümlerde bu sorular yanıtlanmıştır.

\section{1. Çalışmaların Yıllara ve Dergilere Göre Dağılımı}

Çalışmalarda zaman dağılımına dikkat edildiğinde son yıllarda liman seçim kriterleri üzerine yapılan çalışmaların arttığı gözlemlenmiştir. Bu artış özellikle 2018 yılından itibaren daha da belirginleşmiş ve farklı dergiler üzerinde yoğunlaşmıştır (Şekil 2).

Şekil 2: Liman Seçim Kriterlerine ilişkin Çalıșmaların Yıllık Dağılımları

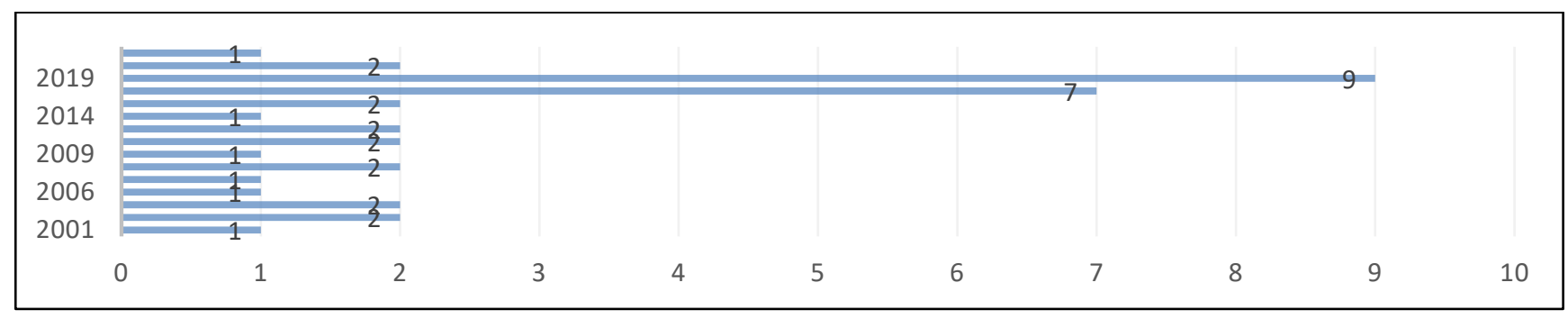

Kaynak: Yazarlar

Çalışmalar dergi isimlerine göre incelendiğinde, özellikle "Maritime Economics \& Logistics" ve "Maritime Policy \& Management" gibi yüksek etki faktörlü deniz taşımacılığı dergilerinin önde oldukları görülmektedir. Örneğin 2018 yılı için "Maritime Economics \& Logistics" dergisinin etki faktörü 1.661, "Maritime Policy \& Management" dergisi için etki faktörü ise 2.5’tir.

Dergilerin etki faktörünün 1'den büyük olması, o derginin alana katkısının tatmin edici olduğunu göstermektedir (Baştuğ vd., 2014: 10). Taşımacılık ve lojistik dergilerinden başka, SSCI ve SCI Expanded endeskli farklı alanlara ait dergilerde de liman seçim kriterleri üzerinde çalışmalar yapıldığı tespit edilmiştir. Bu çalışmaların dağılımları Tablo 6'da sunulmuştur.

Örneğin 2018 yılı için "Maritime Economics \& Logistics” dergisinin etki faktörü 1.661, "Maritime Policy \& Management" dergisi için etki faktörü ise 2.5'tir. Dergilerin etki faktörünün 1'den büyük olması, o derginin alana katkısının tatmin edici olduğunu göstermektedir (Baştuğ vd., 2014: 10). Taşımacılık dergilerinden başka, SSCI ve SCI - Expanded endeskli farklı alanlara ait dergilerde de 
liman seçim kriterleri üzerinde çalışmalar yapıldığı tespit edilmiştir. Bu çalışmaların dağılımları Tablo 6'da sunulmuştur.

Tablo 6: Dergilere göre Çalışmaların Dağılımı

\begin{tabular}{|l|l|c|}
\hline No & Dergi İsmi & Adet \\
\hline 1 & Maritime Economics \& Logistics & 6 \\
\hline 2 & Maritime Policy \& Management & 4 \\
\hline 3 & Transport Reviews & 3 \\
\hline 4 & The Asian Journal of Shipping and Logistics & 3 \\
\hline 5 & Int. J. Shipping and Transport Logistics & 2 \\
\hline 6 & Int. Journal of Physical Distribution \& Logistics Management & 1 \\
\hline 7 & Journal of ETA Maritime Science & 1 \\
\hline 8 & Applied Economics & 1 \\
\hline 9 & Journal of Shipping and Trade & 1 \\
\hline 10 & Energy Policy & 1 \\
\hline 11 & Marine Policy & 1 \\
\hline 12 & Journal of Global Business and Social Entrepreneurship & 1 \\
\hline 13 & Planning Perspective & 1 \\
\hline 14 & Transportation Research Part D & 1 \\
\hline 15 & Transportation & 1 \\
\hline 16 & Transportation Research Part A & 1 \\
\hline 17 & Energy Policy & 1 \\
\hline 18 & Research in Transportation Business \& Management & 1 \\
\hline 19 & Sustainability & 1 \\
\hline 20 & EconStar & 1 \\
\hline 21 & Utilities Policy & 1 \\
\hline 22 & Thermal Science & 1 \\
\hline 23 & International Journal Of Transport Economics & 1 \\
\hline
\end{tabular}

\section{2. Çalışmaların Ülkelere Göre Dağılımı}

Çalışmalarda Çin'in yedi (7) bilimsel araştırma ile ağırlı̆̆ı olup, Türkiye son yıllarda yapılan çalışmalar ile alan yazında ön plana çıkmaktadır. Çin ve Türkiye'den sonra, gelişmiş ekonomilere sahip ülkelerde yapılan çalışmalarda önemli bir orana sahiptir. Araştırmalarda özellikle Batı Avrupa ve Asya etkisi görülmektedir (Şekil 3).

Şekil 3: Liman Seçim Kriterlerine ilişkin Çalışmaların Ülkesel Dağılımları

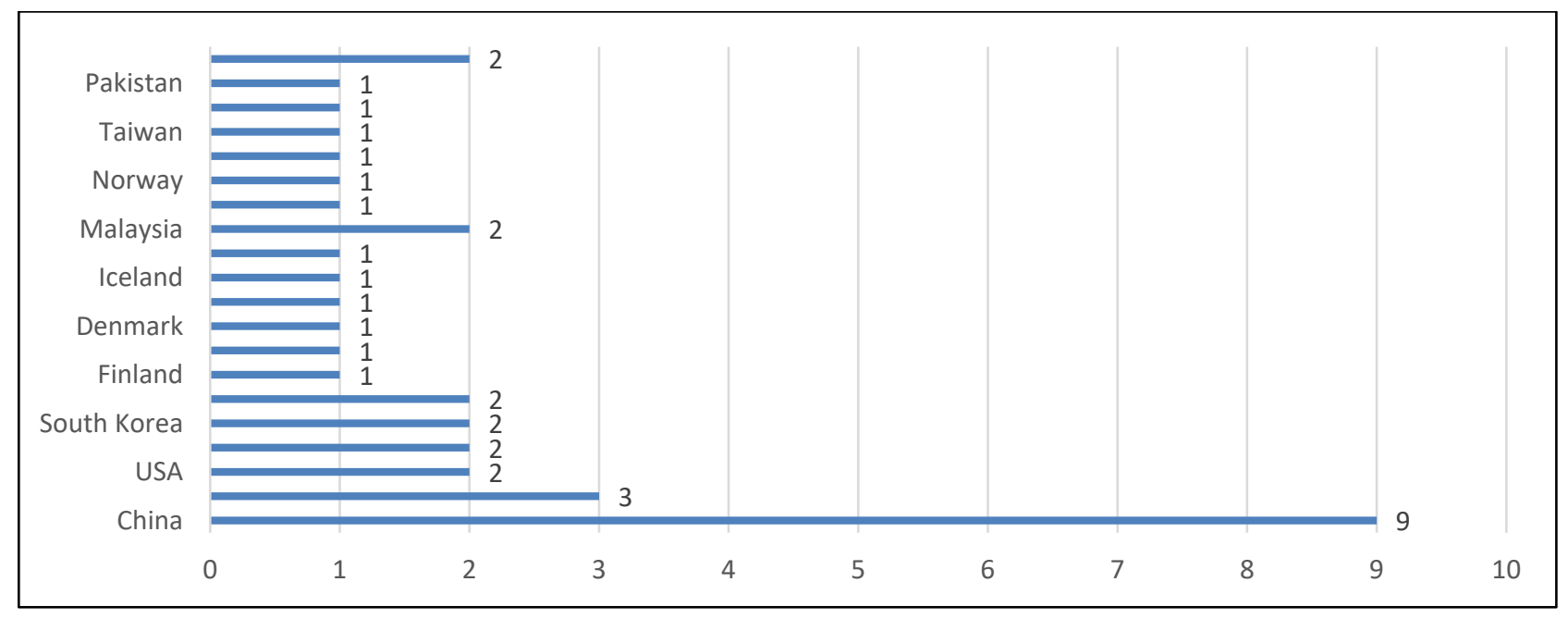

Kaynak: Yazarlar 


\section{3. Çalışmalarda Kullanılan Analiz Yöntemlerine Göre Dağılım}

Örnekleme ihtiyaç duymaması, karşılaştırmalı analizi kolaylaştırması ve sürekli bir şekilde tekrar edilmesinde sunduğu kolaylıklar nedeniyle yapılan çalışmalarda çoğunlukla vaka analizi (8) tercih edilmiştir. Özellikle sosyal bilimlerde karar verme süreçleri üzerine yapılan çalışmalarda sıkça rastlanan matematiksel modelleme ve analitik hiyerarşi süreç analizi de en çok kullanılan analiz yöntemleri olarak tespit edilmiştir. Bununla beraber, yapılması çok kolay ve temel analiz gerektiren çalışmalarda ise SWOT analiz yöntemi tercih edilmiştir (Şekil 4).

Şekil 4: Liman Seçim Kriterlerine ilişkin Çalışmaların Araştırma Analiz Yöntemlerine göre Dağılımları

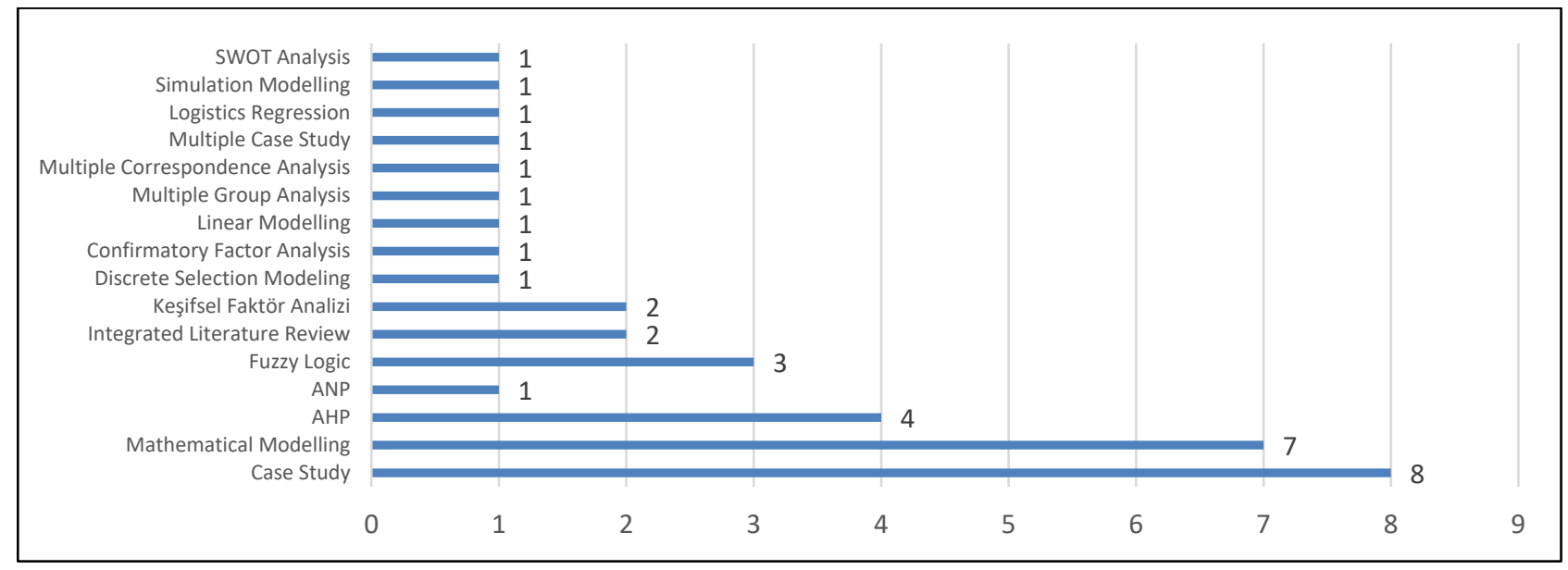

\section{Kaynak: Yazarlar}

\section{5. İÇERİK ANALİŻ}

$\mathrm{Bu}$ kısımda, örneklemi oluşturan makaleler üzerinde içerik analizi yapılarak, en çok çalışılan kategorilerin hangileri olduğu tespit edilmiştir. Krippendorff (2018: 18) 'a göre içerik analizi, verilerden (veya yazılı ve sözlü materyallerden) anlamlı ilişkilere doğru genellenebilir ve geçerli çıkarımlar yapmak vasıtasıyla kullanılan bir araştırma tekniğidir. Örneklemdeki verilerin analizinde NVIVO 12.0 nitel içerik analiz yazılımı kullanılmıştır. İçerik analizinde tema ve kümeler, sistematik literatür taraması sonucu bulunan ana kategori ve alt kategorilerdir. Makaleler, analiz için NVIVO yazılımı ile dijital metinler haline dönüştürülmüşlerdir.

Geleneksel içerik analizinde, araştırma ekibi kodlama şeması oluşturur ve içeriği analiz etmeden önce kodlayıcıları eğitir. Araştırmacılar ve bilim insanları, kodlayıcılar arasındaki öznel yorumları azaltılmak için çeşitli algoritma ve yazılımlar geliştirmişlerdir (Krippendorff, 2018: 218). Yazılımlar sayesinde frekans tablosu oluşturularak benzer belgeler üzerinde defalarca içerik analizi uygulanabilmektedir. Çalışmada kodlayıcılar arasında güvenilirliğin artırılması için benzer çalışmalara katılan ve kodlama yapmak üzere eğitim almış uzmanlardan iki kodlayıcı seçilmiştir. İki kodlayıcının kodlamalarının karşılaştırılması sonucu Kohen-Kappa katsayı puanlarının 0,65'ten az olmadığı görülmüştür. Bu durum kodlanan metinler arasında mutabakat olduğunu göstermektedir (McHugh, 2012: 279). Eğer iki kodlayıcı da hangi içeriğin kodlanacağı konusunda tam bir mutabakata varmışsa, Kappa katsayısı 1 olur. İki kullanıcı arasında (tesadüfi olaylar haricinde) bir mutabakat yok ise, Kappa katsayısı $\leq$ 0'dır. 0 ile 1 arasındaki değer ise kısmi mutabakatı gösterir. Bu durumda çalışmanın kısmı mutabakata vardığı görülmektedir. Araştırma amacı doğrultusunda kategoriler arasındaki ilişkiler matris kodlaması ile incelenmelidir. Özellikle, matris kodlama sorguları ana 
kategoriler ve kavramların boyutlarını tanımlamak, vakalar ve kavramlar arasında çoklu karşılaştırmalar yapmak için kullanılır (Krippendorff, 2018: 81). Başka bir deyişle, matris kodlaması kategorilerdeki anahtar kelimelerden oluşan farklı bağlamları karşılaştırabilir. Bu sonuçlar her satıra karşılık gelen öğe çiftiyle ilgili bilgilerin görüntülediği tablolarda sunulur (örneğin, kümeler, kategorilere göre kodlanmış referanslar veya karşılık gelen kodlanmış veri yüzdesi). Matris kodlaması, verileri frekans, süre, kodlama referansları, satır ve sütun yüzdeleri ile kodlama oranı olarak sorgulayabilir. Bu çalışmada, kategoriler arasındaki kodlama farklılıklarını karşılaştırmak için kodlama referansları kullanılmıștır. Kodlama referansları, röportajlar, odak gruplar, web sayfaları, sosyal medya ilanları, makaleler veya anketler gibi veri kaynaklarından toplanan bilgilere dair anahtar kelime koleksiyonunu gösterir. Matris kodlamasında özel kelimeler ve karakterler operatör olarak kullanılabilir.

\section{BULGULAR}

Liman seçim kriterleri üzerine yapılan içerik analizi (bkz. Şekil 5) göstermektedir ki, maliyet faktörleri 1990 ile 2020 arasındaki 30 yıllık periyodda en çok çalışılan konudur. Daha iyi bir müşteri değeri yaratmak isteyen liman işletmesinin rakipleri karşısında pazarda avantaj yaratabilmesi için maliyetlerini düşürmesi gereklidir. Maliyetlerin düşmesi fiyat belirlemede çok etkili olmaktadır. Araştırmada incelenen birçok çalışma (Esmer, 2011: 94; UNCTAD, 1995: 167), liman yatırımlarının yüksek maliyetli ve yatırım geri dönüş süresinin uzunluğu nedeniyle fiyatlandırma stratejilerinin stratejik olması gerektiğini vurgulamaktadır.

Şekil 5: Liman Seçim Kriterlerine ilişkin Ana Kriterlerin Kodlama Frekansları

(Kodlama Ref. Sayısına göre)

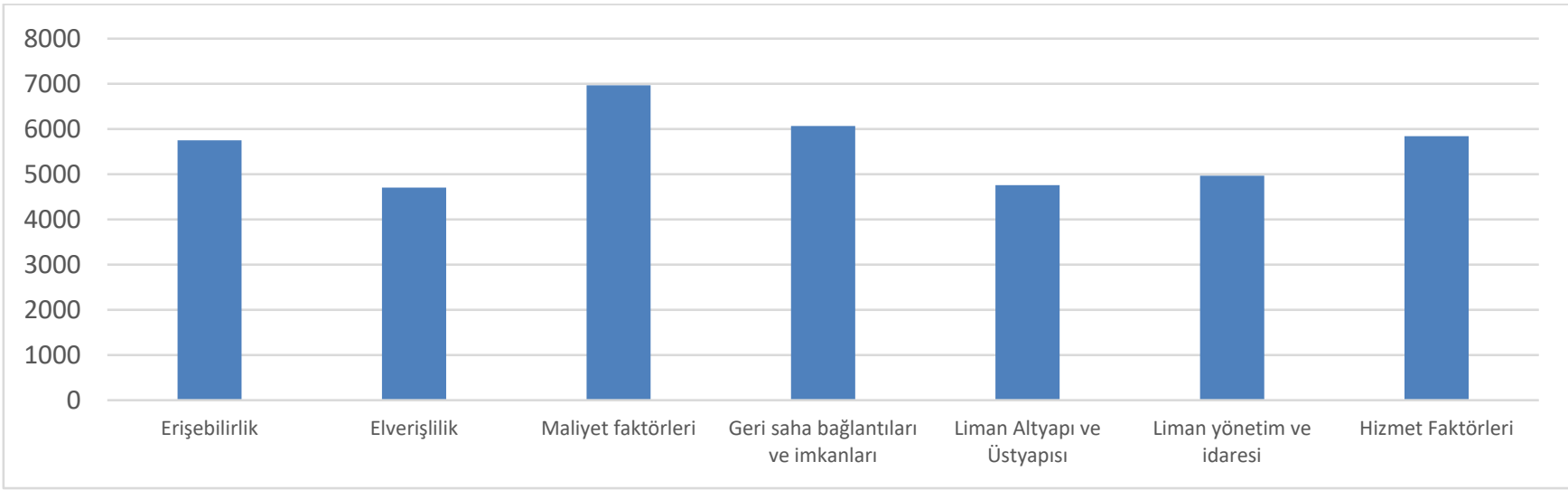

Maliyet faktörleri içinde en çok çalışılan konu ise liman tercihinden kaynaklı toplam lojistik maliyetleri ile fiyatlarda esnekliktir (Şekil 6). Liman tercihinden kaynaklı lojistik maliyetler THC (terminal handling cost), LCL (less than container load), dökümantasyon, elleçleme, depolama masrafları ile liman vergileri olarak literatürde belirtilmektedir. Ayrıca, bu çalışmalarda liman lojistik maliyetlerinin hesaplanmasında statik veya dinamik yöntemler kullanılmaktadır. Liman seçim kriterlerine ilişkin yapılan çalışmalarda elverişlilik kategorisinin en az çalışılan kriter olduğu tespit edilmiştir. Liman çalışanları ile ilgili yapılan çalışmaların azlığı, limancılıkta yeni teknolojilere ilișkin (özellikle Sanayi 4.0) araştırmaların inovasyon odaklı gelişmesi özellikle bu kriterin kodlama referansını aşağıya çekmektedir.

Diğer yandan, liman fiyatlandırma stratejileri ise üç kategoride incelenebilir (Frankel, 1987:71-76; Esmer, 2011:94): maliyet bazlı fiyatlandırma stratejileri, değer bazlı fiyatlandırma stratejileri ve rekabet bazlı fiyatlandırma stratejileri. Bulgular göstermektedir ki literatürde maliyet bazlı 
fiyatlandırma stratejileri 30 senelik periyod içerisinde üzerinde en çok çalışılan ve bilgi üretilen kriterdir.

Şekil 6: Maliyet Faktörüne ilişkin Alt Kriterlerin Kodlama Frekansları

(Kodlama Ref. Sayısına göre)

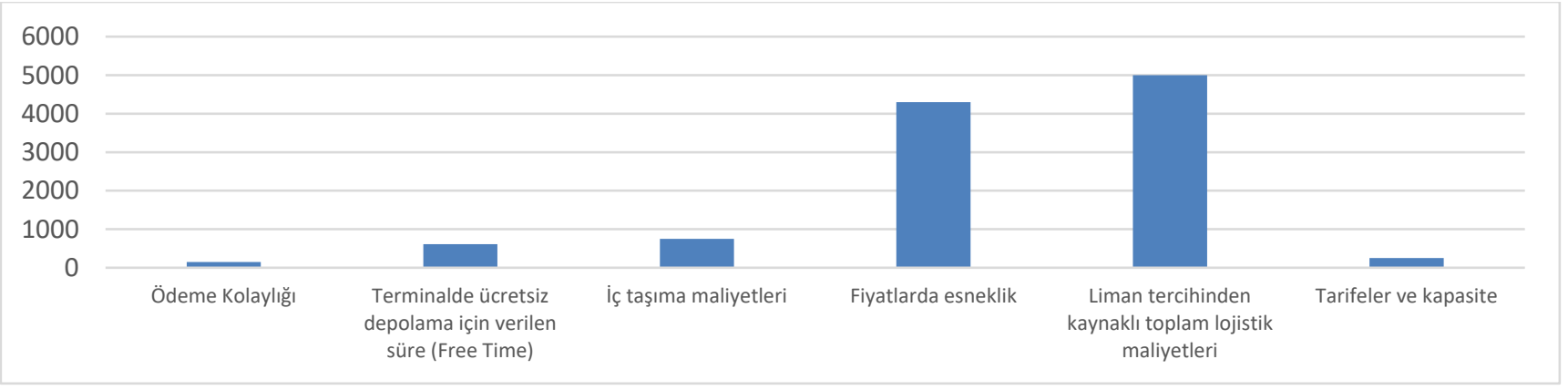

\section{SONUÇLAR VE GELECEK ÇALIŞMALAR İÇİN ÖNERİLER}

Coğrafi konum, altyapı, üst yapı ve ekipman kombinasyonları gibi unsurlar dikkate alındığında her limanın detaylarda benzersiz bir yapıda olduğu sonucuna ulaşılabilir. Ancak liman kullanıcılarının limanlardan beklentileri belirli kriterler etrafında şekillenmektedir. Limanlar hizmet üreten işletmeler olarak farklı yük ve gemi türlerine hizmet vermektedir. Gemilerin limanlarda geçirdikleri zamanı azaltma beklentisi, gemi tiplerinde olduğu gibi limanlarda da yük tipine göre ihtisaslaşmaya yol açmıştır. Bu ihtisaslaşma sonucunda kuru dökme yük, sıvı dökme yük, genel yük ve yolcu terminalleri gibi alt liman tipleri ortaya çıkmıştır. Bu çalışma konteyner yüküne hizmet veren konteyner terminallerine ve konteyner yükünü taşıyan ve ayrıca konteyner terminallerinin kullanıcısı (müşterisi) olan konteyner gemi hatlarına odaklanmıştır. Konteyner gemi hattının, konteyner terminalini seçerken dikkate aldığı kriterler hakkında alan yazında oldukça fazla sayıda araştırma bulunması, fakat bu çalışmaların ekonomik ve teknolojik değişimleri göstermemeleri, bu çalışmaların sistematik olarak incelenmesi ihtiyacını ortaya çıkarmıştır. Bu sayede liman kullanıcıları liman seçimi yaparken dikkate alacakları kriterleri hiyerarşik olarak değerlendirme imkânına sahip olacaktır.

$\mathrm{Bu}$ amaçla yapılan araştırma sonucunda maliyet faktörlerinin en yüksek değerlere sahip olduğu görülmüştür. Bu sonuçlar özellikle terminal operatörleri için dikkate alınması gereken bir içeriğe sahiptir. Çünkü konteyner hat operatörleri ile çalışırken maliyetlerin kontrolü çok büyük önem arz etmektedir. Buna benzer şekilde Acosta, Coronado, \& Mar Cerban (2007)'nın çalışmasında da liman maliyetlerinin konteyner hatları için önemli olduğu ortaya çıkmış, fakat aynı faktörün liman kullanıcıları için çok önemli olmadığını vurgulamışlardır. Onlara göre, limanın lokasyonu, geri saha bağlantısı ve imkanları bir liman kullanıcısı için daha önemlidir. Aslında bu durum maliyet kriteri ile de bir nebze ilişkilidir. Çünkü, liman kullanıcıları lojistik maliyetlerin düşük olması için yükün yükleneceği lokasyon olarak en yakın limanı tercih etmektedirler. Parola vd. (2016), liman maliyetlerinin liman rekabeti üzerine yazılan literatürdeki önemine değinseler de, bu kriterin hangi alt maliyetin bir birleșeni olduğunu araștırmadıkları görülmektedir. Bu çalışma göstermektedir ki liman tercihinden kaynaklı toplam lojistik maliyetlerin özellikle liman kullanıcıları açısından en önemli kriter olduğu tespit edilmiştir. Böylelikle yükün daha az hasar alması ve taşıma süresinin kısalması gibi önemli avantajlar elde edilmektedir. Ayrıca, liman kullanıcılarının tarife ve kapasite, ödeme kolaylığı, ücretsiz depolama için verilen süre ve iç taşıma maliyetlerinden ziyade liman işletmelerinden fiyatlarında esneklik göstermelerini bekledikleri görülmektedir. Burada dikkat çeken nokta, liman kullanıcılarının stratejik bir karar verdiği hem limanı seçerken dikkat ettiği, hem de liman işletmesiyle fiyat üzerinde de pazarlık ederek rekabetçi üstünlük elde etmeye çalıştıkları 
literatürde yer almaktadır. Fiyat pazarlığı yapmak aslında maliyetlerin hat operatörleri ile liman kullanıcıları arasındaki transfer kabiliyetlerine bağlıdır. Tongzon (2009)'a göre yük talep esnekliğinin değişmediği hallerde, konteyner hat operatörlerinin maliyet transferinde daha hassas davrandıklarını ve özellikle gemilerin fuzuli beklemelerini müşterilerine veya forwarder'lara direk yansıtıklarını ortaya koymuştur. Bu durum, liman kullanıcılarının terminal seçimlerini etkileyen önemli bir rekabet faktörüdür.

$\mathrm{Bu}$ araştırma liman seçim kriterlerinin sistematik bir sınıflandırmasını yapması bakımından gelecekte bu konuda yapılacak çalışmalar için tanımlayıcı bir niteliğe sahiptir. Sonraki çalışmalarda bu çalışma kapsamında tanımlanan temel liman seçim kriterleri ile denizciliğin özel alanlarına ilişkin alt çalışmalar yapılabilir. Deniz taşımacılığında kullanılan ana ticari rotalar üzerinde yer alan düğüm noktalarında ya da aktarma bölgelerinde kümelenen limanlar arasında sadece transit konteynere yönelik çalışmaların yapılmasının literature katkı sağlayacağı düşünülmektedir. 


\section{KAYNAKCCA}

Acosta, M., Coronado, D., \& Mar Cerban, M. (2007). Port competitiveness in container traffic from an internal point of view: the experience of the Port of Algeciras Bay. maritime Policy \& management, 34(5), 501-520.

Akbayırlı, K., Deveci, D. A., Balcl, G., \& Kurtuluş, E. (2016). Container port selection in contestable hinterlands. Journal of ETA Maritime Science, 4(3), 249-265.

Baştuğ, S., Altuntaş, C., Eriş, E. D., \& Okan, T. U. N. A. (2014). Türkiye'de Lojistik Sektörü: Epistemolojik Doküman Analiz Tekniği İle Stratejik Bir Değerlendirme. Beykoz Akademi Dergisi, 1(2), 7-24.

Bichou, K. (2014). Port operations, planning and logistics. CRC Press.

Eisenhardt, K. M. (1989). Agency theory: An assessment and review. Academy of management review, 14(1), 57-74.

Esmer, S. (2011). Liman İşletmelerinde Hizmet Pazarlaması. Detay Yayıncılık: Ankara

Esmer, S. ve Çetin Ç. K. (2013). Liman İşletme Yönetimi, Denizcilik İşletmeleri Yönetimi, 513-515.

Frankel, Ernest G. (1987). Port Planning and Development. John Wily \& Sons. Inc, USA.

Goss, R. (1990). Economic policies and seaport: Part 4 - strategies for port authorities. Maritime Policy and Management 17(4): 1-28.

Kim, A. R. (2016). A Study on Competitiveness Analysis of Ports in Korea and China by Entropy Wight TOPSIS. The Asian Journal of Shipping and Logistics. 32(4) 187-194.

Krippendorff, K. (2018). Content analysis: An introduction to its methodology. Sage publications.

Lagoudis, I. N., Theotokas, I., \& Broumas, D. (2017). A literature review of port competition research. International Journal of Shipping and Transport Logistics, 9(6), 724-762.

Lam, J. S. L. (2015). Designing a sustainable maritime supply chain: A hybrid QFD-ANP approach. Transportation Research Part E: Logistics and Transportation Review, 78, 70-81.

Lirn, T. C., Thanopoulou, H. A., Beynon, M. J., \& Beresford, A. K. C. (2004). An application of AHP on transhipment port selection: a global perspective. Maritime Economics \& Logistics, 6(1), 70-91.

Mayring, P. (2000). Qualitative Content Analysis, Forum Qualitative Sozialforschung / Forum: Qualitative Social Research, 1.2, (accessed 7th December 2006), Available from: http://www.qualitative-research.net/fqs-texte/2-00/2-00mayring-e.htm

Miles, M. B., Huberman, A. M., Huberman, M. A., \& Huberman, M. (1994). Qualitative data analysis: An expanded sourcebook. sage.

Munim, Z. H., \& Saeed, N. (2019). Seaport competitiveness research: the past, present and future. International Journal of Shipping And Transport Logistics, 11(6), 533-557.

Parola, F., Risitano, M., Ferretti, M., \& Panetti, E. (2016). The drivers of port competitiveness: a critical review. Transport Reviews, 37(1), 116-138.

Porter, M. E. (1980). Competitive Strategy, New York: The Free Press

Robinson, R. (2002). Ports as elements in value-driven chain systems: the new paradigm. Maritime Policy and Management 29(3): 241-255.

Saeed, N. (2009). An analysis of carriers' selection criteria when choosing container terminals in Pakistan. Maritime Economics \& Logistics, 11(3), 270-288. 
Salinas Andújar, J. A., Guarnido Rueda, A., \& Amate Fortes, I. (2012). Determining Factors in Port Competitiveness: the Case of Fresh Fruit and Vegetable Produce Traffic in Spanish Ports. Determining Factors in Port Competitiveness: the Case of Fresh Fruit and Vegetable Produce Traffic in Spanish Ports., 313-328.

Sayareh, J., ve Alizmini, H. R. (2014). A hybrid decision-making model for selecting container seaport in the Persian Gulf. The Asian Journal of Shipping and Logistics, 30(1), 75-95.

Seuring, S. and Gold, S. (2012). Conducting content-analysis based literature reviews in supply chain management, Supply Chain Management: An International Journal, 17(5), 544-555.

Song, D. W., ve Yeo, G. T. (2015). A Competitive Analysis of Chinese Container Ports Using the Analytic Hierarchy Process. In Port Management (pp. 339-359). Palgrave Macmillan UK.

Tongzon, J. L. (2009). Port choice and freight forwarders. Transportation Research Part E: Logistics and Transportation Review, 45(1), 186-195.

UNCTAD (1995). Marketing Promotion Tools for Ports. New York.

UNCTAD (2019). Review of Maritime Transport. Genève

Yap, W. Y., Lam, J. S., \& Notteboom, T. (2006). Developments in container port competition in East Asia. Transport Reviews, 26(2), 167-188.

Yeo, G. T., \& Song, D. W. (2006). An application of the hierarchical fuzzy process to container port competition: policy and strategic implications. Transportation, 33(4), 409-422.

Yeo, G. T., Roe, M., \& Dinwoodie, J. (2008). Evaluating the competitiveness of container ports in Korea and China. Transportation Research Part A: Policy and Practice, 42(6), 910-921.

Yuen, Kum Fai, Vinh V. Thai, and Yiik Diew Wong. (2017). Corporate social responsibility and classical competitive strategies of maritime transport firms: A contingency-fit perspective. Transportation Research Part A: Policy and Practice 98, 1-13. 


\section{EXTENDED ABSTRACT}

\section{Determinants of Sustainable Port Competitiveness for Transit Container Market: A Systematic Literature Review}

\section{Introduction}

According to UNCTAD (United Nations Conference on Trade and Development), 24.4 million (12\%) of the total 197.6 million TEU (twenty-foot equivalent unit, 20-year-old containers) of containers were transported on the Far East-Europe route around the world in 2019. In the same year, the total number of containers handled at the world's ports reaches a volume of approximately 800 million TEU. Turkey is located on the Far East-Europe main trunk and transit routes, especially for the foreign trade cargoes of Black Sea countries. Despite the high capacities of our port facilities, many ports face difficulties in sustainable port competition due to inefficiency in port operations, poor service delivery and problems in commercial operations. Our ports need to be directed towards management and strategic direction in order to increase their competitiveness in their regions.

As a hinterland connection and an integrated platform of sea and land transportation, ports serve to transfer logistics, production, information and international trade, and then serve as a stepping stone for the economic development of the backfield. In order to be performed properly, ports must serve ships and other modes of transportation efficiently and effectively. Due to its importance in trade, ports play a critical role in the transfer of economic prosperity to national and international economies.

Therefore, this research aims to determine the criteria that our container ports will follow for achieving sustainable competitive advantage and the research questions addressed as follows:

1. What are the major criteria that determine sustainable port competition in the container transportation market?

2. What criteria stand out in the literature among the determinants of port competition?

\section{Data Set and Method}

Regarding Seuring and Gold (2012:545), systematic literature review consists of four stages, including collection of data, descriptive statistics, identification of the main categories and data examination. During the collection of the data, the first sample was obtained and these studies were eliminated according to internal and external criteria and afterward the studies were reached in the first sample. In the next stage, descriptive statistics about studies by chronological, countries and research types were prepared. An identification of the main categories was carried out in line with the theoretical framework and data reduction was carried out and the categories were consolidated. According to Miles and Huberman (1994:91), the process of examining data from the main categories consists of three basic stages. These stages are: (1) data reduction, (2) data display, and (3) data interpretation. For these stages, the basic framework of categories and sub-criteria is established on the basis of the current theory, all categories are consolidated in the coding process. In the continuation of data reduction, iteration cycle method was used in the coding of categories belonging to sub-criteria.

Finally, content analysis has divided into two stages. In the first stage, the content of the document is examined by using statistical methods, and in the second stage, the existence of certain words and concepts is investigated by interpreting the meanings underlying the terms and inferences. 


\section{Empirical Findings}

Content analysis on port selection criteria shows that cost factor is the most studied topic in the 30year period between 1990 and 2020. In order to create a better customer value, the port business needs to reduce its costs in order to gain an advantage over its competitors in the market. Lowering costs is very effective in setting prices. Many studies (Esmer, 2011: 94; UNCTAD, 1995:167) emphasizes that pricing strategies should be strategic due to the high cost of port investments and the length of the return on investment. The most studied issue among the cost factors is flexibility in prices with total logistics costs arising from port preference. In the literature, logistics costs arising from port preference are stated as THC (terminal handling cost), LCL (less container load), documentation, handling, storage costs and port tariffs. Additionally, static or dynamic methods are used in these studies to calculate port logistics costs. The findings show that cost-based pricing strategies are the most studied and knowledge-generated criteria in the literature over a 30-year period. In contrast, it was determined that the category "convenience" is the least studied criterion.

\section{Discussion and Conclusion}

As a result of the research, controlling costs is very important when working with container line operators. Similarly, the study of Acosta, Coronado, \& Mar Cerban (2007) found that port costs were important for container lines, but they emphasized that the same factor was not very important for port users. According to them, port location, hinterland connection and the port facilities are the most important for the port users. In fact, this is somewhat related to the cost criterion. Because port users prefer the nearest port as the location where the cargo will be loaded in order to reduce logistics costs. This study also shows that total logistics costs arising from port preference have been determined to be the most important criterion, especially for port users. In this way, significant advantages, such as less damage to the cargo and shortening the transit time are obtained. In addition, port users expect that terminal operators obtain flexibility in their prices rather than tariffs and capacity, ease of payment, free time and local transportation costs. Negotiating prices actually depends on the transfer capabilities of costs between line operators and port users. According to Tongzon (2009), when the flexibility in the cargo demand has not been changed, container line operators are more sensitive to cost transfer. This is an important competitive factor affecting the terminal choices of port users. 